\title{
Austrian students' experiences of supportive relationships with teachers, peers, and parents and the mediating effect of school belonging in the context of their academic and non-academic outcomes
}

\author{
Gerda Hagenauer (D) C Christina Wallner-Paschon (iD · Clara Kuhn (i)
}

Received: 30 September 2020 / Revised: 9 April 2021 / Accepted: 13 April 2021 / Published online: 6 May 2021

(C) The Author(s) 2021

\begin{abstract}
Based on the assumption that people are driven by an innate need for relatedness, the present study explores the interrelations between students' perceptions regarding supportive relationships, their sense of belonging at school, and academic and non-academic outcomes. More concretely, we hypothesise that students who experience high teacher support (as indicated by teacher fairness), high emotional support from parents, and low bullying in class exhibit a higher sense of school belonging, which, in turn, is positively related to life satisfaction and achievement and negatively related to school absenteeism. Differences in gender and differences concerning migration background were also explored as well as possible differences in the structural relations across groups. The results of our analysis, which is based on the PISA 2015 dataset for Austrian students, mainly confirm the hypothesised associations and also confirm the function of students' sense of school belonging as a mediator. Regarding group differences, female students and students without a migration background tended to report higher values regarding perceived supportive relationships and school belonging. However, life satisfaction of female students was lower than that of male students. Overall, the results suggest that supportive relationships between students and their teachers, classmates, and parents should be fostered, as such supportive relationships are directly and indirectly correlated with important student outcomes.
\end{abstract}

G. Hagenauer $(\bowtie) \cdot$ C. Kuhn

School of Education, Department of Educational Science, School Research and School Practice, University of Salzburg, Erzabt-Klotz-Straße 1, 5020 Salzburg, Austria

E-Mail: gerda.hagenauer@sbg.ac.at

C. Kuhn

E-Mail: clara.kuhn@sbg.ac.at

C. Wallner-Paschon

Department 1-Scientific Products, Unit 1/2-International Studies, IQS-Federal Institute for Quality Assurance of the Austrian School System, Alpenstraße 121, 5020 Salzburg, Austria

E-Mail: christina.wallner-paschon@iqs.gv.at 
Keywords Supportive relationships $\cdot$ School belonging $\cdot$ Life satisfaction $\cdot$ School absenteeism · Achievement · PISA-2015

\section{Unterstützende Sozialbeziehungen von österreichischen Schüler*innen mit Lehrkräften, Peers und Eltern und der mediierende Effekt der schulischen Zugehörigkeit bezogen auf schulische und außerschulische Outcomes}

Zusammenfassung Basierend auf der Annahme, dass alle Menschen das Bedürfnis nach sozialer Eingebundenheit aufweisen, wurde in der Studie überprüft, inwiefern Sozialbeziehungen, die Schüler*innen als unterstützend erfahren, mit der Schulzugehörigkeit und akademischen und nichtakademischen Outcomes zusammenhängen. Es wurde angenommen, dass Schüler*innen, die unterstützende Beziehungen mit Lehrpersonen erleben (gekennzeichnet durch Fairness), emotional von den Eltern unterstützt werden und wenig Bullying-Erfahrungen in der Schule machen, ein höheres Gefühl der Schulzugehörigkeit erleben, das wiederum positiv mit der Lebenszufriedenheit und der Leistung und negativ mit dem Schulabsentismus in Verbindung steht. Ebenso wurden Geschlechterunterschiede und Unterschiede zwischen Schüler*innen mit und ohne Migrationshintergrund untersucht, sowie mögliche Unterschiede in den Zusammenhängen zwischen den Variablen über die Gruppen hinweg. Die Ergebnisse, die auf den PISA-2015-Daten aus Österreich beruhen, bestätigen die angenommenen Zusammenhänge sowie die Mediatorfunktion der Variable „Schulzugehörigkeit““ weitgehend. Im Hinblick auf Gruppenunterschiede berichteten Mädchen und Schüler*innen ohne Migrationshintergrund stärker unterstützende Sozialbeziehungen und ein höheres Gefühl der Schulzugehörigkeit. Allerdings berichteten Mädchen auch von einer geringeren Lebenszufriedenheit. Aus den Ergebnissen lässt sich ableiten, dass die Förderung unterstützender Beziehungen zu Lehrpersonen, Eltern und Mitschüler*innen von Bedeutung ist, da diese direkt und indirekt mit relevanten Schüler*innenmerkmalen in Verbindung stehen.

Schlüsselwörter Sozialbeziehungen · Schulzugehörigkeit · Lebenszufriedenheit · Schulabsentismus · Leistung · PISA 2015

\section{Introduction}

Ryan and Deci's $(2000,2017)$ self-determination theory (SDT) provides that effective functioning in life requires the satisfaction of three basic psychological needs: autonomy, competence, and relatedness. The satisfaction of such needs predicts peoples' well-being (Ryan and Deci 2017). Addressing the need for relatedness, Baumeister and Leary (1995) developed the 'belongingness hypothesis', suggesting that people thrive through positive relationships. Thus, when humans fulfil their innate need for quality interpersonal relationships and thereby their sense of belonging, this can have crucial effects on their cognitions, emotions, motivation, behaviour, health, and well-being (Baumeister and Leary 1995; Ryan and Deci 2000). 
Children and adolescents spend much of their time at school, constantly interacting with their classmates and teachers and, consequently, forming relationships with them (Tian et al. 2016). The quality of these relationships, as well as their relationships with their parents, is a precondition for optimal school functioning and general well-being (Ahmadi and Ahmadi 2020). It can be assumed that a variety of variables mediate this association.

Taking up this line of argument, the present study aimed to examine the interrelations between students' supportive relationships with teachers, peers, and parents and their academic and non-academic outcomes by accounting for students' sense of belonging at school (SOBS) as a mediator (Osterman 2000). SOBS is defined as 'the extent to which students feel personally accepted, respected, included, and supported by others in the school social environment' (Goodenow and Grady 1993, p. 80). If students feel connected to school or, in other words, if they feel a sense of school belonging, their innate need to belong (Baumeister and Leary 1995; Ryan and Deci 2017) is met, and thus, various benefits resulting from a high SOBS are expected.

In our analyses, we relied on the 2015 PISA data from Austria. Aside from two studies by Eder $(1995,2007)$, there has been limited research based on representative samples examining the quality of Austrian students' supportive relationships in school and at home and SOBS.

\section{Theoretical background}

\subsection{Self-determination theory and the need for relatedness}

Many theories address the universal and innate need to belong and the need for relatedness (e.g., for an overview, see Allen and Bowles 2012). In school-based research, SDT has been largely used to investigate the impact of the fulfilment of the need for relatedness on students' experiences and behaviour at school. SDT is a macrotheory of motivation that focuses on social conditions that either 'facilitate or hinder human flourishing' (Ryan and Deci 2017, p. 3). One of SDT's core assumptions is that there are three basic psychological needs-autonomy, competence, and relatedness - that, if satisfied, foster self-motivation, personality integration, psychological growth, and well-being. The failure to meet these needs is harmful to individuals (Ryan and Deci 2000).

SDT's basic psychological needs theory has been applied to a variety of settings, including schools (Klaeijsen et al. 2018; Tian et al. 2016). In a school setting, students' need for autonomy, for example, is met when they can make their own decisions, are involved in class or school decision-making processes, and view their school-based activities as relevant. The need for competence at school is the desire to succeed in learning and become proficient, whereas the need for relatedness refers to the need to feel positively connected to teachers, peers, and parents (Xiang et al. 2017). Fulfilment of the need for relatedness leads to many important outcomes for young people, as summarised by Martin and Dowson (2009): 'Theory and research supports the proposition that positive relationships with significant others are cor- 
nerstones of young people's capacity to function effectively in social, affective, and academic domains' (p. 351).

Various antecedents contribute to the fulfilment of the need for relatedness. One significant factor thereof is supportive social relations or, more generally, a supportive social environment (e.g., Zumbrunn et al. 2014). If students feel supported, strong connections are fostered and the fulfilment of the need for relatedness is boosted. Sakiz (2012) argues that 'teacher support is one of the key elements for high-quality teacher-student relationships' (p. 63). However, not only teachers, but also peers and parents, are significant providers of support to students. Consequently, we propose that supportive relationships with teachers (e.g., as characterized by fairness and mutual respect; Allen et al. 2018), peers (e.g., as characterized by trust and integration or just by having friends; Allen et al. 2018) and parents (e.g., as characterized by emotionally supportive and caring behaviour; Allen et al. 2016, 2018) are at the core of students' fulfilment of the need to belong and, consequently, their SOBS (OECD 2019a; Slaten et al. 2016).

\subsection{The role of school belonging}

Students' SOBS is a psychological concept that has received increased attention in the last two decades in Anglo-American countries (for an overview, see Allen et al. 2018; Korpershoek et al. 2020; Osterman 2000), however, it is still rather underresearched in German-speaking countries. In the literature, the term 'school belonging' has been frequently used interchangeably with other concepts, such as school connectedness, bonding, relatedness, sense of community, or acceptance (Korpershoek et al. 2020; Osterman 2000). However, as Slaten et al. (2016, p. 4) argue, the difference is not mainly due to differences in the conceptual understanding or definition, but merely an issue of the used or preferred terminology. The most frequently cited definition by Goodenow and Grady (1993) for SOBS has already been introduced in the previous section highlighting the role of perceived integration in the social environment as the core feature of SOBS. Allen et al. (2016) provide a similar definition claiming that '[SOBS] is one's feeling of being connected to a school within a school social system' (pp. 98-99).

Students' SOBS is influenced by interactions between many micro-, meso-, and macro-level factors (Bronfenbrenner 1977). Amongst these influences, the quality of support from teachers, peers, and parents is a significant and core determinant on the micro-level (Longaretti 2020), with previous studies indicating that teacher support is the most influential factor (Allen et al. 2016, 2018; Arends and Visser 2019). Apart from supportive relationships with teachers and peers, it is also important for students to perceive support from their parents. If students observe that education is important to their parents - that parents place value on their school performance and ultimately, that their educational efforts are supported - they feel safe and encouraged, and, consequently, their SOBS is inclined to be positively fostered as well (Allen et al. 2018).

Regarding demographic differences, female students typically report a slightly higher SOBS than their male counterparts (Allen et al. 2018; Arends and Visser 2019; Bond et al. 2007; Chiu et al. 2012; Gillen-O'Neel and Fuligni 2013; Huyge 
et al. 2015). Additionally, students from migration backgrounds exhibit a lower SOBS in a variety of different countries (Chiu et al. 2012; Ham et al. 2017; Schachner et al. 2018), which is frequently explained by a higher degree of discrimination.

Turning to the benefits of students' SOBS, previous studies have claimed that students' SOBS is associated with a variety of academic and non-academic benefits. According to Allen and Bowles (2012), if students feel as if they belong to school, they tend to have lower probabilities of maladaptive behaviour, whereas they experience more physical and psychological well-being. Furthermore, in comprehensive reviews and meta-analyses, Osterman (2000) and Korpershoek et al. (2020) suggest a positive link between students' SOBS and their academic achievement as well as their motivation (e.g., mastery approach goals) and engagement (e.g., academic effort and cognitive engagement) (see also the meta-analysis by Allen et al. 2018, for the various benefits of SOBS).

In this study, we focused on three outcome variables reflecting the following categories of student outcomes: students' achievement in maths, reading, and science; school absenteeism as an indicator of maladaptive behaviour; and life satisfaction as a core element of subjective well-being. Therefore, supportive relationships are not only directly related with desirable academic and non-academic outcomes for students, but they are also simultaneously mediated through students' SOBS, suggesting partial mediation.

\subsection{Students' academic and non-academic outcomes}

\subsubsection{Students' achievement}

Positive, stable, and supportive relationships with others form an optimal basis for students' exploration and perceptions of safety in learning processes (Bergin and Bergin 2009). Hence, in general, positive relationships are positively linked to students' motivation, emotions, engagement, and, consequently, their achievement (Martin and Dowson 2009). Similar correlations have also been found for students' SOBS. Overall, studies have identified a positive correlation between achievement, positive and supportive relationships, and SOBS (Osterman 2000; Zumbrunn et al. 2014), although the link was not equally observable in all studies. This inconsistency may be because different studies have used different measures of achievement (e.g., grades vs. standardised achievement tests) and samples with different demographic characteristics (e.g., gender, age, ethnicity). For example, Arends and Visier (2019) found weak correlations between relationship quality, SOBS, and achievement for grade 5 students based on the 2015 TIMSS dataset. On the other hand, GillenO'Neel and Fuligni (2013) and Wormington et al. (2016) did not detect any correlation between SOBS and GPA based on students' grades. In a recent meta-analysis, Korpershoek et al. (2020) detected a correlation of 0.18 between SOBS and school grades (based on $n=67$ studies) and a correlation of 0.12 between standardised test scores and SOBS (based on $n=19$ studies). 


\subsubsection{School absenteeism}

Students who do not have positive and supportive relationships at school and, consequently, have a lower SOBS are at greater risk of engaging in maladaptive behaviours in general (e.g., health-risk behaviours such as drinking alcohol; McNeely and Falci 2004) and in school-related misconduct specifically. Studies have identified correlations between negatively perceived relationships and low SOBS and school absenteeism (defined as being absent from school without permission or valid excuse; Sälzer 2010; Stamm 2006). Korpershoek et al. (2020) reported a negative correlation between absence data and SOBS of -0.16 . Furthermore, Bond et al. (2007) found that students in grade 8 who reported a high SOBS exhibited a greater likelihood of completing grade 12 compared with those who felt less connected to school. In another study, Wormington et al. (2016) highlighted a positive link between peer victimisation and school absenteeism, mediated by students' SOBS; students who were victimised by their classmates felt less connected to school, which resulted in more frequent absences.

\subsubsection{Life satisfaction}

According to SDT, positive and supportive relationships with others and a sense of feeling connected are fundamental to the fulfilment of students' needs for relatedness and, thus, are relevant indicators of well-being (Arslan 2018; Jose et al. 2012; Newman et al. 2007). According to Diener (2000), subjective well-being comprises two main components: life satisfaction (i.e., an individual's subjective cognitive evaluation of their life) and positive affect (i.e., experiencing positive emotions). In PISA 2015, only life satisfaction was assessed.

Previous research has shown that a high SOBS is positively associated with life satisfaction (Aldridge et al. 2020; Datu and Valdez 2019). In addition, positive relationships with teachers, classmates, and parents (Suldo et al. 2008) also exhibit direct significant associations with life satisfaction (Hagenauer et al. 2018). Thus, SOBS appears to function as a mediator for the outcome of life satisfaction (Ahmadi and Ahmadi 2020).

\subsection{The present study}

Previous studies have suggested that there are relevant associations between the quality of students' perceived supportive relationships with teachers, classmates, and parents (synonymously referred to as teacher, peer, and parent support; Allen et al. 2018), their SOBS and their academic (achievement and school absenteeism) and non-academic (life satisfaction) outcomes. However, much remains to be learned about how these factors interrelate once they are considered simultaneously in a model. For example, concerning SOBS, Allen et al. (2018) argued that previous research has focused predominantly on single factors in terms of influencing and outcome variables. In light of this claim, the present study extends previous research by taking into account a variety of theoretically derived antecedents and outcomes simultaneously, although some restrictions in terms of the availability of 
variables needed to be accepted, as the study used an existing dataset (PISA 2015). Furthermore, the particular mechanism that links the quality of supportive relationships with desirable outcomes on the students' side needs further investigation. Incorporating SOBS as a potential mediator variable progresses the field further, in order to explain how supportive relationships are connected to students' outcomes. This research question is particularly important with respect to German-speaking countries, where research on SOBS has been rather limited to date. The present study aimed to test the interrelations between the aforementioned factors based on a representative sample of Austrian students. The following hypothesis was tested:

The perceived quality of supportive relationships with teachers, parents, and peers as part of the social environment is positively related to students' SOBS, which in turn correlates positively with their achievement and life satisfaction and negatively with school absenteeism. Thus, SOBS can be regarded as a mediator variable. More concretely, partial mediation is assumed (e.g., Wormington et al. 2016). Direct effects between the perceived quality of supportive relationships and the proposed outcome variables are also expected.

The hypothesis was grounded at the level of an individual student, as we were interested in the individual perceptions of students on the proposed factors and their interrelations. This is in line with Demant and Houtte's (2012) argument claiming that the individual level has significantly more power for explanation of student outcomes based on their perceived school belonging compared with the school level as a unit of analysis.

There has been a lack of research to date examining non-cognitive student factors in Austria based on representative samples. Thus, this paper discusses descriptive statistics for the entire sample, and our analysis tested group differences concerning gender and migration background. We hypothesised that female students and students with non-migration backgrounds would report more positive experiences at school in terms of supportive relationships and SOBS. Accordingly, female students and students with non-migration backgrounds were expected to report higher life satisfaction and lower school absenteeism.

Achievement-related group differences have already been investigated comprehensively in Austria, as achievement is at the core of the PISA study: It is expected that female students outperform their male counterparts in reading, while the achievement is higher for male students in maths and science. With regard to migration background, it is expected that students without a migration background exhibit higher achievement levels compared with their native counterparts (Suchan and Breit 2016).

Finally, we also explored whether the relations between the constructs differ between girls and boys and students with and without a migration background. 


\section{Method}

\subsection{Sample}

The present study was based on the Austrian PISA 2015 sample. PISA assesses country-representative samples of 15-16 year-old students. ${ }^{1}$ In 2015, the Austrian PISA sample consisted of 7007 students from 269 schools. The survey used a twostage stratified sample design. The first stage consisted of a sampling of schools, and the second stage consisted of a sampling of students within the sampled schools. Austria reached a participation rate of $99 \%$ at the school level and $87 \%$ at the student level, fulfilling the required quality standards (OECD 2016, pp. 288-294). We relied on PISA 2015 data in our study because teacher support as reflected by teacher fairness was one of the core variables with regard to supportive relationships, and it was not assessed in Austria in PISA 2018.

\subsection{Measures}

Teacher fairness as an indicator of teacher support Teacher fairness refers to the fairness and level of respect of teacher behaviour as perceived by the students. According to the literature, teacher fairness can be regarded as a significant characteristic of teacher support, although it does not entail aspects such as care and concern for students, which are typically also part of teachers' support (Sakiz et al. 2012; Sakiz 2012). Thus, teacher fairness must be understood as one specific facet of teacher support. Students rated the frequency of specific teacher behaviours in the 12 months preceding the survey (six items, e.g., 'Teachers ridiculed me in front of others' and 'Teachers disciplined me more harshly than other students') on a scale from 1 to 4 (i.e., $1=$ never or almost never; $4=$ once a week or more) (OECD 2017a, p. 299; Cronbach's $\alpha=0.79$ ). A high value of the items reflected teacher unfairness; thus, the items were recoded in order to achieve a scale where a higher score indicated the presence of teacher fairness.

Bullying/victimisation as an indicator of a lack of peer support The extent of experienced bullying is an indicator of the quality of relationships that students have with their peers. In the PISA study, bullying is defined as 'negative physical or verbal actions that have hostile intent, cause distress to victims, are repeated and involve a power differential between perpetrators and victims' (OECD 2019a, p. 273). The students were asked to rate how often they had experienced different types of peer victimisation in the 12 months preceding the survey (eight items; e.g., 'I got called names by other students' and 'I was threatened by other students') on a scale from 1 to 4 (i.e., $1=$ never or almost never; $4=$ once a week or more) $($ OECD 2017a, p. 299; Cronbach's $\alpha=0.87$ ).

\footnotetext{
1 The target population of PISA in 2015 in Austria was students born between 1 August 1999 and 31 July 2000. Therefore, at the time of the test, $68 \%$ of the tested students were 15 and $32 \%$ were 16 .
} 
Parents' emotional support as an indicator of parent support To measure parents' support and interest in the students' schooling, four items were answered by the students (e.g., 'My parents support me when I am facing difficulties at school' and 'My parents encourage me to be confident') on a scale from 1 to 4 (i.e., $1=$ do not agree at all; $4=$ completely agree) (OECD 2017a, p. 317; Cronbach's $\alpha=0.79$ ).

SOBS SOBS was measured with six items in PISA in 2015. We excluded two items that directly addressed positive interactions with classmates to prevent a high concept overlap with the independent variables. Accordingly, students' SOBS was measured with four items (e.g., 'I feel like I belong at school') on a scale from 1 to 4 (i.e., $1=$ completely agree; $4=$ do not agree at all) (OECD 2017a, p. 305; Cronbach's $\alpha=0.83$ ).

Life satisfaction Students rated their general life satisfaction on a scale from $0=$ not satisfied at all to $10=$ very satisfied $($ OECD 2017a, p. 196).

School absenteeism The students were asked to rate how often they had either skipped a whole day of school or some lessons during the day and how often they had come late to school during the previous two weeks. These three items were rated on a scale from $1=$ never, to $4=$ five times or more (Cronbach's $\alpha=0.67$ ).

Students' achievement Students' achievement is reported based on ten plausible values for each competence. By building on these plausible values, a composite of students' PISA test scores in maths, science, and reading was used as an achievement measure for the structural equation model, while the achievement scores were used separately for testing group differences. Detailed information on the achievement literacy framework and the scaling of the achievement items is available from the Technical Report of PISA 2015 (OECD 2017a, pp. 225ff).

Migration background Students whose parents were both born abroad were coded as students with a migration background. Hence, students from a nonmigration background had at least one parent born in Austria (OECD 2016, p. 281).

Gender Gender was assessed with a dichotomous variable $(1=$ female; $0=$ male $)$.

ESCS The index of economic, social, and cultural status (ESCS) was derived from three variables related to the students' family backgrounds: parents' highest level of education, parents' highest occupational status, and home possessions (including books at home). The ESCS scale was transformed, with 0 being the score of an average OECD student and 1 being the standard deviation across equally weighted OECD countries (OECD 2017a, p. 339f).

\subsection{Data analysis}

The PISA data has a complex sampling design and hierarchical data. In order to account for sampling issues, all analyses were done by utilising the final student 


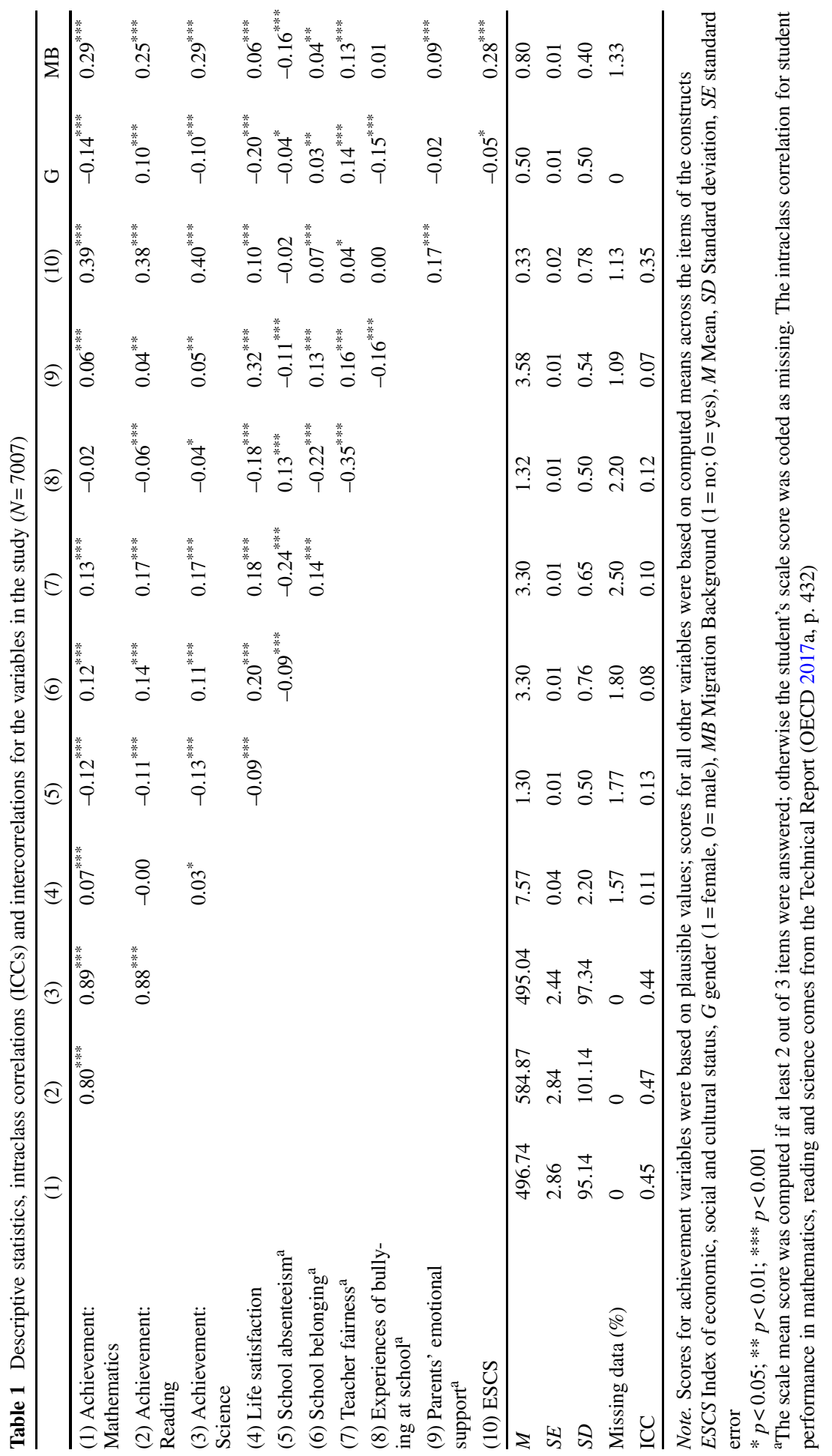


weight and the stratification variable (stratification = schooltype) to get an exact estimate of the population of 15-year-old Austrian students (OECD 2016, p. 298). In order to account for the nested structure of the data (students in schools) the Mplus (Muthén \& Muthén, 1998-2017) command 'type= complex' was used (cluster variable: school ID). Due to the proposed hypotheses on the individual level and the interest in students' individual and subjective perceptions, we did not include predictor variables at the school level.

Furthermore, in order to handle the plausible values to calculate students' achievement scores, the Mplus command 'type=imputation' was employed. The analyses related to group differences were performed using the IEA International Database Analyzer 4.0.35. This software also considers the complex sample design of PISA (i.e., students nested in schools) and provides the correct standard errors.

The intraclass correlations (ICCs) ranged from 0.07 to 0.13 for the dependent variables (SOBS, absenteeism, and bullying) on the school level. The ICCs for students' achievement were higher, as already reported by the OECD (2017a; see Table 1 for the ICCs of all variables). This is plausible as Austria has a tracked school system that differentiates between high and low track schools. Typically, students with a higher socio-economic background attend high-track schools more frequently. In order to control for this effect, students' socioeconomic status was entered as covariate.

In order to test for relations between the constructs, structural equation modelling (SEM) with Mplus version 7 (Muthén \& Muthén, 1998-2017) was employed using maximum likelihood estimates with robustness to non-normality (MLR) and full information maximum likelihood estimation (FIML) to handle the missing data.

To analyse the indirect effects, the bootstrapping method was used, with 10,000 samples and maximum likelihood (ML). 95\% bias-corrected confidence intervals were calculated. The procedure was conducted in Mplus by applying the command 'indirect model'. While the MLR-SEM was estimated ten times to accurately assess students' achievement with different plausible values, the ML-SEM for measuring the indirect effects was estimated with only one plausible value (see Table 5).

Model fit was assessed with common fit indices: CFI, TLI, RMSEA, and SRMR. If CFI and TLI exceed 0.95 and RMSEA and SRMR are below 0.06, a good model fit is achieved. If CFI and TLI are between 0.90 and 0.95, and RMSEA and SRMR are below 0.08, an acceptable model fit exists (Hu and Bentler 1999).

Statistical significance was assessed according to a predetermined significance level of $\alpha=0.05$, whereas practical significance was assessed by interpreting standardised path coefficients $\beta$ as effect size measurements. According to Cohen (1988), values of $|\beta| \geq 0.10$ may be cautiously interpreted as small effects, $|\beta| \geq 0.30$ as moderate effects, and $|\beta| \geq 0.50$ as large effects.

Reliability analyses and computations of scale means were performed in IBM SPSS Statistics 26. The scale mean scores were only computed if a student had answered at least 2 out of 3 items; otherwise, the scale mean score was coded as missing. 


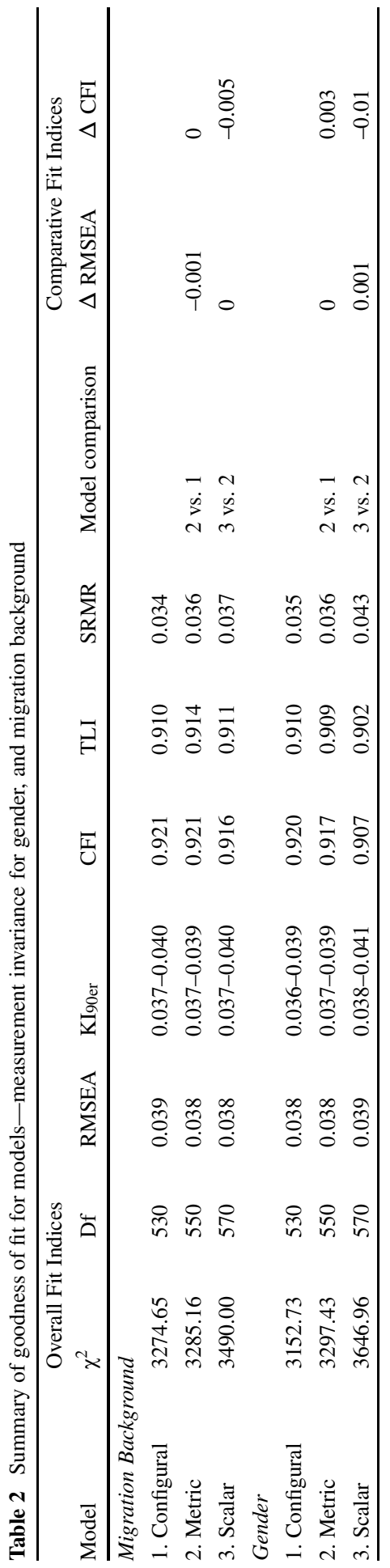


Table 3 Gender differences

\begin{tabular}{|c|c|c|c|c|c|c|}
\hline & \multicolumn{2}{|c|}{$\begin{array}{l}\text { Female students } \\
(N=3443)\end{array}$} & \multicolumn{2}{|c|}{$\begin{array}{l}\text { Male students } \\
(N=3564)\end{array}$} & \multicolumn{2}{|c|}{$\begin{array}{l}\text { Differences } \\
\text { (Female-male students) }\end{array}$} \\
\hline & $M$ & $S D$ & $M$ & $S D$ & Sig & $d$ \\
\hline Teacher fairness & $\begin{array}{l}3.38 \\
(0.01)\end{array}$ & 0.59 & $\begin{array}{l}3.21 \\
(0.02)\end{array}$ & 0.70 & $* * *$ & 0.27 \\
\hline $\begin{array}{l}\text { Experiences of } \\
\text { bullying at school }\end{array}$ & $\begin{array}{l}1.24 \\
(0.01)\end{array}$ & 0.42 & $\begin{array}{l}1.39 \\
(0.01)\end{array}$ & 0.55 & $* * *$ & -0.30 \\
\hline $\begin{array}{l}\text { Parents' emotional } \\
\text { support }\end{array}$ & $\begin{array}{l}3.57 \\
(0.01)\end{array}$ & 0.57 & $\begin{array}{l}3.59 \\
(0.01)\end{array}$ & 0.51 & n.s & -0.04 \\
\hline School belonging & $\begin{array}{l}3.33 \\
(0.01)\end{array}$ & 0.74 & $\begin{array}{l}3.28 \\
(0.01)\end{array}$ & 0.78 & $* *$ & 0.06 \\
\hline Life satisfaction & $\begin{array}{l}7.09 \\
(0.05)\end{array}$ & 2.32 & $\begin{array}{l}7.95 \\
(0.04)\end{array}$ & 1.97 & $* * *$ & -0.40 \\
\hline School absenteeism & $\begin{array}{l}1.28 \\
(0.01)\end{array}$ & 0.46 & $\begin{array}{l}1.32 \\
(0.02)\end{array}$ & 0.54 & n.s. & -0.08 \\
\hline $\begin{array}{l}\text { Reading achieve- } \\
\text { ment }\end{array}$ & $\begin{array}{l}495.08 \\
(3.66)\end{array}$ & 98.22 & $\begin{array}{l}474.85 \\
(4.29)\end{array}$ & 102.93 & $* * *$ & 0.20 \\
\hline $\begin{array}{l}\text { Mathematic } \\
\text { achievement }\end{array}$ & $\begin{array}{l}483.13 \\
(3.58)\end{array}$ & 91.22 & $\begin{array}{l}510.10 \\
(3.81)\end{array}$ & 96.99 & $* * *$ & -0.29 \\
\hline $\begin{array}{l}\text { Science achieve- } \\
\text { ment }\end{array}$ & $\begin{array}{l}485.53 \\
(3.15)\end{array}$ & 93.12 & $\begin{array}{l}504.37 \\
(3.57)\end{array}$ & 100.44 & $* * *$ & -0.19 \\
\hline
\end{tabular}

Note. Results weighted by PISA total student weight; standard errors are in parentheses; $N=$ unweighted $d=$ Cohen's $\mathrm{d} ;|\mathrm{d}| \geq 0.20=$ small effect; $|\mathrm{d}| \geq 0.50=$ medium effect; $|\mathrm{d}| \geq 0.80=$ large effect

$* p<0.05 ; * * p<0.01 ; * * * p<0.001$

\section{Results}

\subsection{Descriptive statistics and correlations}

As shown in Table 1, the intercorrelations were largely as hypothesised: the more positive the experienced social relationships, the higher were students' SOBS, life satisfaction, and achievement and the lower was school absenteeism. However, the correlations were generally only small to moderate $(r \leq-0.35)$. Small positive correlations were found between SOBS and the achievement dimensions as well as life satisfaction. The achievement dimensions were strongly correlated with each other. The covariates (ESCS, gender, and migration background) were significantly related to the quality of the perceived supportive relationships, SOBS, achievement, and life satisfaction; thus, they needed to be controlled for in the analysis model. The highest association was with students' ESCS.

\subsection{Differences between boys and girls and students with and without a migration background}

Before mean differences were calculated, a multi-group confirmatory factor analysis was applied to test for measurement invariance of the model across the different groups of students (girls and boys; students with and without a migration background; Millsap 2012). In order to test for invariance, the change of two fit 
Table 4 Differences between students with and without a migration background

\begin{tabular}{|c|c|c|c|c|c|c|}
\hline & \multicolumn{2}{|c|}{$\begin{array}{l}\text { Non-migration back- } \\
\text { ground }(N=5609)\end{array}$} & \multicolumn{2}{|c|}{$\begin{array}{l}\text { Migration back- } \\
\text { ground } \\
(N=1319)\end{array}$} & \multicolumn{2}{|c|}{$\begin{array}{l}\text { Differences } \\
\text { (Non-migration background- } \\
\text { migration background) }\end{array}$} \\
\hline & $M$ & $S D$ & $M$ & $S D$ & Sig & $d$ \\
\hline $\begin{array}{l}\text { Teacher fair- } \\
\text { ness }\end{array}$ & $\begin{array}{l}3.34 \\
(0.01)\end{array}$ & 0.63 & $\begin{array}{l}3.13 \\
(0.03)\end{array}$ & 0.71 & $* * *$ & 0.32 \\
\hline $\begin{array}{l}\text { Experiences } \\
\text { of bullying at } \\
\text { school }\end{array}$ & $\begin{array}{l}1.32 \\
(0.01)\end{array}$ & 0.49 & $\begin{array}{l}1.30 \\
(0.02)\end{array}$ & 0.49 & n.s. & 0.03 \\
\hline $\begin{array}{l}\text { Parents' emo- } \\
\text { tional support }\end{array}$ & $\begin{array}{l}3.60 \\
(0.01)\end{array}$ & 0.52 & $\begin{array}{l}3.49 \\
(0.01)\end{array}$ & 0.60 & $* * *$ & 0.20 \\
\hline $\begin{array}{l}\text { School belong- } \\
\text { ing }\end{array}$ & $\begin{array}{l}3.32 \\
(0.01)\end{array}$ & 0.76 & $\begin{array}{l}3.24 \\
(0.02)\end{array}$ & 0.77 & $* *$ & 0.10 \\
\hline $\begin{array}{l}\text { Life satisfac- } \\
\text { tion }\end{array}$ & $\begin{array}{l}7.59 \\
(0.04)\end{array}$ & 2.12 & $\begin{array}{l}7.26 \\
(0.08)\end{array}$ & 2.44 & $* * *$ & 0.15 \\
\hline $\begin{array}{l}\text { School absen- } \\
\text { teeism }\end{array}$ & $\begin{array}{l}1.26 \\
(0.01)\end{array}$ & 0.47 & $\begin{array}{l}1.45 \\
(0.02)\end{array}$ & 0.58 & $* * *$ & -0.37 \\
\hline $\begin{array}{l}\text { Reading } \\
\text { achievement }\end{array}$ & $\begin{array}{l}498.69 \\
(2.69)\end{array}$ & 96.80 & $\begin{array}{l}434.96 \\
(5.98)\end{array}$ & 99.99 & $* * *$ & 0.65 \\
\hline $\begin{array}{l}\text { Mathematic } \\
\text { achievement }\end{array}$ & $\begin{array}{l}511.52 \\
(2.77)\end{array}$ & 90.47 & $\begin{array}{l}442.09 \\
(4.88)\end{array}$ & 91.18 & $* * *$ & 0.76 \\
\hline $\begin{array}{l}\text { Science } \\
\text { achievement }\end{array}$ & $\begin{array}{l}509.98 \\
(2.37)\end{array}$ & 93.26 & $\begin{array}{l}439.64 \\
(4.55)\end{array}$ & 91.06 & $* * *$ & 0.76 \\
\hline
\end{tabular}

Note. Results weighted by PISA total student weight; standard errors are in parentheses; $N=$ unweighted; $d=$ Cohen's $\mathrm{d} ;|\mathrm{d}| \geq 0.20=$ small effect; $|\mathrm{d}| \geq 0.50=$ medium effect; $|\mathrm{d}| \geq 0.80=$ large effect

$* p<0.05 ; * * p<0.01 ; * * * p<0.001$

indices-CFI and RMSEA - between nested models was investigated. If the change in CFI ( $\triangle$ CFI) is not more than 0.01 (Cheung and Rensvold 2002) and the change in RMSEA ( $\triangle$ RMSEA) is not more than 0.015 (Chen 2007), invariance can be assumed. The $\chi^{2}$-difference test was not employed as it strongly depends on the sample size (Kelloway 2017; Schermelleh-Engel et al. 2003).

The results support the assumption of scalar respective strong invariance (i.e. same factor loading and intercepts in the constructs for girls and boys and students with and without a migration background; see Table 2). This indicates that group differences can be tested.

After measurement variance was confirmed, group differences were tested. First, regarding students' gender, the results show, that girls perform significantly better in reading $(d=0.20)$ while boys perform significantly better in mathematics $(d=-0.29)$ and science $(d=-0.19)$. Findings further show that female students perceived teacher fairness as significantly higher than male students $(d=0.27)$, and they felt a significantly stronger SOBS $(d=0.06)$. Male students, on the other hand, reported experiencing bullying at school more often than female students $(d=0.30)$, and they reported significantly higher life satisfaction $(d=-0.40)$. However, most effect sizes can only be interpreted as small effects (see Table 3 ).

Second, we were interested in differences between students with and without migration backgrounds (see Table 4). Medium effects were found in the three achieve- 


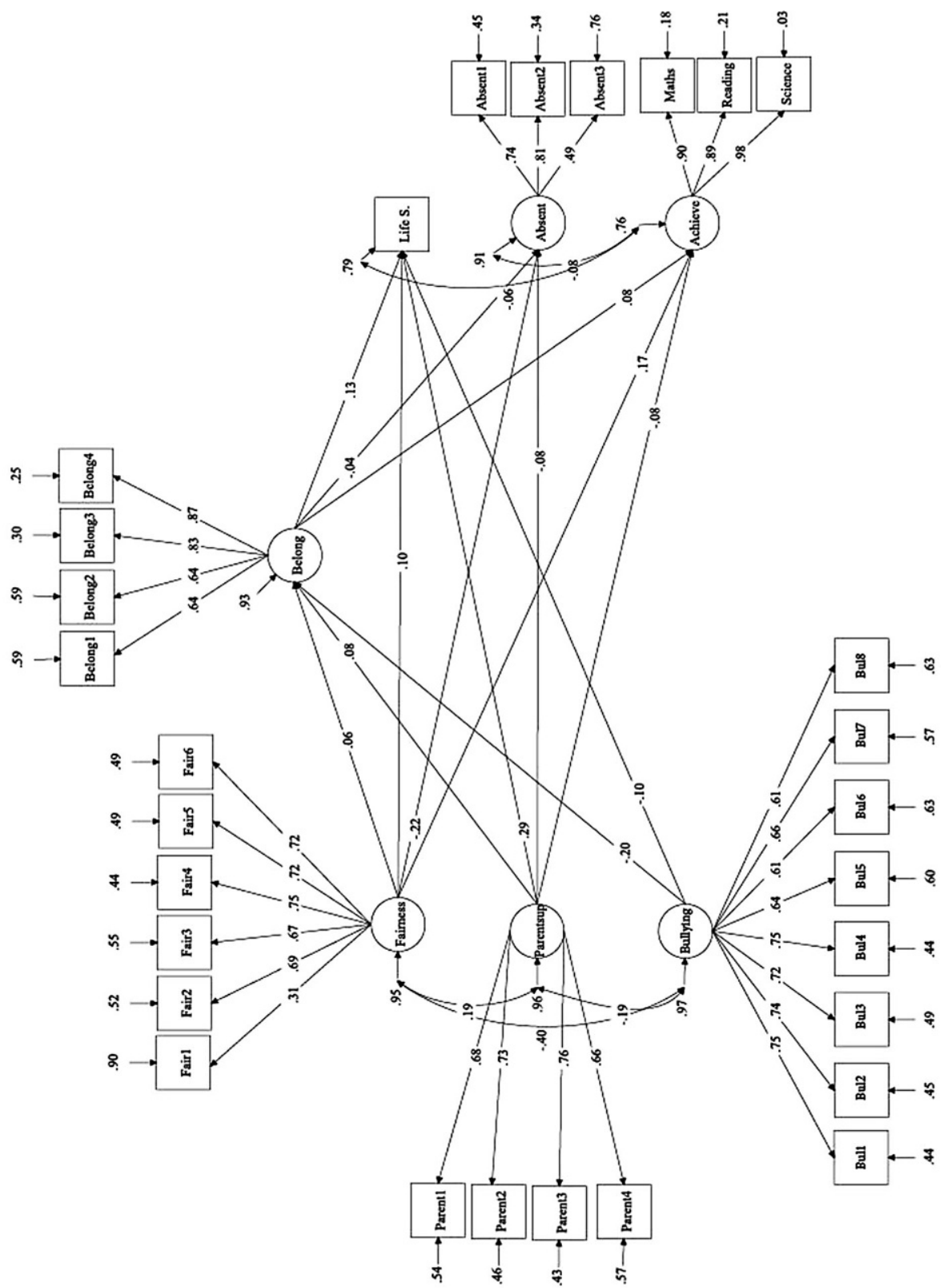

Fig. 1 Structural equation model testing for the relationships between the quality of social relationships, school belonging (as mediator), life satisfaction, school absenteeism and achievement $(N=6887)$. Maximum likelihood estimations with robust standard errors (MLR). TLI $=0.899, \mathrm{CFI}=0.911, \mathrm{RMSEA}=0.039$, SRMR $=0.036$. Note. Only significant effects $(p<0.01)$ are shown as standardised coefficients $(\beta)$. Paths pertaining to the covariates are not depicted 
Table 5 Structural equation model testing for the indirect relationships between the quality of social relationships, school belonging (as mediator), life satisfaction, school absenteeism and achievement $(N=6887)$ : Bootstrapping results for the indirect effects in the model

\begin{tabular}{|c|c|c|c|c|c|}
\hline & \multicolumn{2}{|c|}{ Standardised estimates } & \multicolumn{3}{|c|}{ Unstandardised estimates } \\
\hline & $\beta$ & $S E$ & $B$ & $S E$ & $\begin{array}{l}95 \% \text { boot- } \\
\text { strap CI }\end{array}$ \\
\hline \multicolumn{6}{|l|}{ Teacher-student relationship } \\
\hline $\begin{array}{l}\text { Teacher fairness } \rightarrow \text { School belong- } \\
\text { ing } \rightarrow \text { Achievement }\end{array}$ & $0.008 * *$ & 0.002 & $1.820 * *$ & 0.557 & $\begin{array}{l}{[0.813} \\
3.022]\end{array}$ \\
\hline $\begin{array}{l}\text { Teacher fairness } \rightarrow \text { School belong- } \\
\text { ing } \rightarrow \text { School absenteeism }\end{array}$ & $-0.003 *$ & 0.001 & $-0.003^{*}$ & 0.002 & $\begin{array}{l}{[-0.007} \\
-0.001]\end{array}$ \\
\hline $\begin{array}{l}\text { Teacher fairness } \rightarrow \text { School belong- } \\
\text { ing } \rightarrow \text { Life satisfaction }\end{array}$ & $0.008 * *$ & 0.003 & $0.051 * *$ & 0.016 & $\begin{array}{l}{[0.022} \\
0.087]\end{array}$ \\
\hline \multicolumn{6}{|l|}{ Student-student relationship } \\
\hline $\begin{array}{l}\text { Bullying } \rightarrow \text { School belong- } \\
\text { ing } \rightarrow \text { Achievement }\end{array}$ & $-0.026^{* * * *}$ & 0.004 & $-3.196 * * *$ & 0.460 & $\begin{array}{l}{[-4.181} \\
-2.387]\end{array}$ \\
\hline $\begin{array}{l}\text { Bullying } \rightarrow \text { School belong- } \\
\text { ing } \rightarrow \text { School absenteeism }\end{array}$ & $0.009^{*}$ & 0.004 & $0.005^{*}$ & 0.002 & $\begin{array}{l}{[0.001} \\
0.010]\end{array}$ \\
\hline $\begin{array}{l}\text { Bullying } \rightarrow \text { School belong- } \\
\text { ing } \rightarrow \text { Life satisfaction }\end{array}$ & $-0.026^{* * * *}$ & 0.004 & $-0.090 * * *$ & 0.012 & $\begin{array}{l}{[-0.116} \\
-0.067]\end{array}$ \\
\hline \multicolumn{6}{|l|}{ Parent-student relationship } \\
\hline $\begin{array}{l}\text { Parents' emotional sup- } \\
\text { port } \rightarrow \text { School belong- } \\
\text { ing } \rightarrow \text { Achievement }\end{array}$ & $0.010 * * *$ & 0.002 & $2.087 * * *$ & 0.517 & $\begin{array}{l}{[1.203} \\
3.217]\end{array}$ \\
\hline $\begin{array}{l}\text { Parents' emotional sup- } \\
\text { port } \rightarrow \text { School belonging } \rightarrow \text { School } \\
\text { absenteeism }\end{array}$ & $-0.004^{*}$ & 0.002 & $-0.004^{*}$ & 0.002 & $\begin{array}{l}{[-0.007} \\
-0.001]\end{array}$ \\
\hline $\begin{array}{l}\text { Parents' emotional sup- } \\
\text { port } \rightarrow \text { School belonging } \rightarrow \text { Life } \\
\text { satisfaction }\end{array}$ & $0.011 * * *$ & 0.002 & $0.059 * * *$ & 0.013 & $\begin{array}{l}{[0.036} \\
0.088]\end{array}$ \\
\hline
\end{tabular}

Note. $* p<0.05 ; * * p<0.01 ; * * * p<0.001$; based on 10,000 bootstrapped samples. Maximum likelihood estimations $(\mathrm{ML}) ; \mathrm{RMSEA}=0.05, \mathrm{SRMR}=0.036$

ment dimensions, whereas only small to no effects were revealed in the others. Looking at the differences in achievement, students without a migration background performed significantly better in reading $(d=0.65)$, maths $(d=0.76)$, and science $(d=0.76)$ than students with a migration background. Moreover, students without a migration background reported a higher experience of teacher fairness $(d=0.32)$, experienced more parental emotional support $(d=0.20)$, reported greater life satisfaction $(d=0.15)$, and had a stronger SOBS $(d=0.10)$. Additionally, students with a migration background had a higher rate of school absenteeism $(d=-0.37)$.

\subsection{Interrelations between quality of perceived supportive relationships and cognitive and non-cognitive outcomes while considering SOBS as a mediator}

To test our hypothesis, structural equation modelling was applied, controlling for gender, ESCS, and migration background. The results (see Fig. 1) found that SOBS was weakly associated with perceived teacher fairness $(\beta=0.06)$, bullying 
Table 6 Summary of goodness of fit for multiple group SEM models—gender and migration background

\begin{tabular}{|c|c|c|c|c|c|c|c|c|c|}
\hline \multicolumn{8}{|c|}{ Overall Fit Indices } & \multicolumn{2}{|c|}{$\begin{array}{l}\text { Comparative Fit } \\
\text { Indices }\end{array}$} \\
\hline Model & $\chi^{2}$ & Df & RMSE & $\mathrm{CFI}$ & TLI & SRMR & $\begin{array}{l}\text { Model } \\
\text { compari- } \\
\text { son }\end{array}$ & $\begin{array}{l}\Delta \mathrm{RM}- \\
\text { SEA }\end{array}$ & $\Delta \mathrm{CFI}$ \\
\hline \multicolumn{10}{|c|}{ Migration Background } \\
\hline $\begin{array}{l}\text { 1. Uncon- } \\
\text { strained } \\
\text { model }\end{array}$ & 5967.66 & 858 & 0.042 & 0.904 & 0.896 & 0.040 & & & \\
\hline $\begin{array}{l}\text { 2. Con- } \\
\text { strained } \\
\text { model }\end{array}$ & 6025.03 & 884 & 0.041 & 0.903 & 0.899 & 0.042 & 2 vs. 1 & 0.001 & 0.001 \\
\hline \multicolumn{10}{|l|}{ Gender } \\
\hline $\begin{array}{l}\text { Unconstrained } \\
\text { model }\end{array}$ & 5724.98 & 856 & 0.041 & 0.905 & 0.897 & 0.042 & & & \\
\hline $\begin{array}{l}\text { Constrained } \\
\text { model }\end{array}$ & 5843.52 & 883 & 0.040 & 0.903 & 0.898 & 0.040 & 2 vs. 1 & 0.001 & 0.002 \\
\hline
\end{tabular}

$(\beta=-0.20)$, and parents' emotional support $(\beta=0.08)$. Weak but significant associations were also detected between SOBS and life satisfaction $(\beta=0.13)$, absenteeism $(\beta=-0.04)$, and achievement $(\beta=0.08)$. Direct effects in the expected direction were found between the perceived quality of supportive relationships and life satisfaction, absenteeism, and achievement, with the strongest associations found between parents' emotional support and life satisfaction $(\beta=0.29)$ and teacher fairness and school absenteeism $(\beta=-0.22)$. However, the association between parents' emotional support and achievement was negative. As shown in Table 4, the test for mediation revealed small indirect effects (for all proposed possible mediations), suggesting that students who experience high teacher fairness, positive parents' emotional support, and little bullying report higher SOBS, which further positively relates with life satisfaction and achievement and negatively with school absenteeism. The strongest indirect effect was detected between perceived bullying, SOBS, life satisfaction, and achievement, respectively, as reflected in Table 5.

\subsection{Multiple group comparisons: gender and migration background}

After testing the model for the whole sample, multi-group SEM modelling was employed to test whether there are differences in the relations between girls and boys and students with and without a migration background. Therefore, an unconstrained model (measurement model was constrained to be equal between groups; structural parameters varied between groups) was compared to a constrained model (measurement model and structural parameters were constrained to be equal across groups; Kleinke et al. 2017). Due to the large sample size, the $\chi^{2}$-difference test was not utilized to compare the two models (Kelloway 2017). Alternatively, we relied on the differences in the fit indices RMSEA and SRMR. As Table 6 depicts, the model fits were satisfactory and did not differ substantially between the unconstrained and 
the constrained model, suggesting similar structural relations for boys and girls and students with and without a migration background.

\section{Discussion}

This study provides insight into the associations between students' perceptions of teacher fairness, parents' emotional support, and bullying; their SOBS (as a mediator); and their life satisfaction, school absenteeism, and achievements based on the Austrian PISA 2015 sample. Differences between female and male students and those with and without a migration background were also tested as well as possible differences in the structural relations across groups.

Controlling for the covariates of gender, ESCS, and migration background, the proposed mediation model was mainly supported, although the majority of the effects were small to medium only, and some effects did not reach practical relevance. In line with expectations, students who reported higher teacher fairness, higher parental emotional support, and fewer bullying tended to exhibit higher SOBS, achievement, and life satisfaction and a lower degree of school absenteeism. The only exception was the negative relation between parents' emotional support and students' achievement.

Thus, the present study confirmed that the quality of perceived supportive relationships with teachers, parents, and peers is of unique importance to students' experiences (SOBS, life satisfaction), behaviour (school absenteeism) and achievement. However, in contrast to Allen et al. $(2016,2018)$, the quality of teacher support (as reflected in teacher fairness in our study) was associated only weakly with students' SOBS and was not the strongest explanatory factor compared with students' supportive relationships with their classmates and parents. This may be because different studies have used different indicators to measure the perceived quality of teacher-student relationships. The teacher-student relationship is multidimensional (Hagenauer and Volet 2014); thus, it is unsurprising that studies have resulted in heterogeneous findings, presumably partly due to their chosen measure. In the present study, we focused on the professional aspect of the teacher-student relationship (i.e., whether teachers treat students fairly and with respect). It would be interesting to test whether including interpersonal aspects of the relationship, such as closeness with teachers, led to comparable findings. We hypothesise that measures that are more closely linked to teacher-student-integration would correlate more strongly to SOBS compared with measures of teacher fairness.

The negative association between parents' emotional support and students' achievement may be explained by the fact that parents support their child more if the child is struggling at school and achieving at a lower level. Similar findings have already been reported with regard to parents' homework support: In crosssectional studies, parents' support related negatively to students' achievement, suggesting that parents with low-achieving students provide higher support overall (for Austria specifically, see Hagenauer and Oberwimmer 2019). This can be regarded as a positive finding, as long as the support is perceived as autonomy-supportive and not controlling or intrusive (Pomerantz and Eaton 2001). As the results were 
correlational only, causal interpretations (e.g., parents' emotional support leads to lower achievement or vice versa) must not be drawn. However, one needs to keep in mind that the bivariate correlations between parents' emotional support and achievement were positive, albeit very low. Thus, a suppressor effect can also not be ruled out.

Concerning students' SOBS, the results confirm that SOBS is positively related to life satisfaction and achievement and negatively related to school absenteeism. The positive, though weak, association between SOBS and achievement, after controlling for various factors, aligns well with the results of Arends and Visser (2019), who analysed 2015 TIMSS data from South Africa. The weak association with life satisfaction may be because the PISA question on life satisfaction did not refer to the school context (i.e., the measure was not context-specific). In the 2018 PISA well-being framework, satisfaction in school was also measured (OECD 2019a) and could be explored in future models.

Overall, the hypothesised indirect effect of positive supportive relationships on students' outcomes via SOBS was confirmed, illustrating the mechanism that connects factors within the perceived relational social environment to students' academic and non-academic outcomes. However, in light of the results of most previous studies that investigated the mediation of SOBS on various outcomes (e.g., Ahmadi and Ahmadi 2020; Datu and Valdez 2019), larger indirect effects were expected (however, for small indirect effects, see also Wormington et al. 2016). Future studies should further investigate the importance of SOBS as a variable that clarifies how supportive relationships are directly and indirectly related to various student outcomes.

Consistent with the results of previous studies (Arends and Visser 2019; Bond et al. 2007), we found that female students had more positive social experiences than male students, with one exception: the life satisfaction of female students was markedly lower than that of male students. This is consistent with the results in most OECD countries based on PISA 2015 and 2018 (OECD 2017b, 2019b), which is in stark contrast to satisfaction in school, where female students typically report higher values (Eder 1995, 2007). Future research, therefore, should investigate the factors that significantly contribute to the higher life satisfaction of male students.

In terms of migration background, students with a migration background had slightly lower results regarding the variables in the study (for similar findings, see also Ham et al. 2017; Schachner et al. 2018), but the effect sizes were not large. Students from migration backgrounds perceived lower teacher fairness and exhibited higher school absenteeism than students from non-migration backgrounds. These two factors might be related: a perception of unfair teacher behaviour leads to avoidant behaviour by the student, which is likely to result in maladaptive behaviours such as skipping class or school.

Finally, as we found similar structural relations across groups, the assumption of the universal nature of the need for belongingness was supported (Baumeister and Leary 1995), suggesting that supportive relationships with others and a sense of belonging may be of similar importance for male and female students as well as students with and without a migration background. 


\subsection{Limitations and directions for future research}

The present study had certain strengths and limitations, leading to several implications for future research. The main strengths were the representative dataset on which the results are based and the complex mediation model that was tested in the analysis. Different supportive relationships and their effects on academic and non-academic student characteristics were simultaneously considered, and indirect effects were accounted for. A major limitation was the cross-sectional nature of the dataset, which did not allow the drawing of any conclusions regarding the causality of the variables. Furthermore, although the model was rather complex, significant additional variables could not be included. For example, motivation and engagement likely function as mediators between students' SOBS and achievement (Zumbrunn et al. 2014). These associations were not modelled in the present analysis and should be examined in future research.

Moreover, the construct of SOBS needs further clarification. It is still open to debate whether positive relationships in general and support specifically can be regarded as a constitutive element of SOBS itself or whether they must be regarded as antecedents. In our analysis, we adopted the second understanding. Future research should theoretically and conceptually clarify the concept of 'school belonging' and ensure that this conceptualisation is adopted in the corresponding empirical measurement.

Overall, to gain a more nuanced understanding of the variables addressed in this study in the Austrian school context, future studies should apply more complex research designs. Longitudinal quantitative designs that allow for testing reciprocal effects and changes over time (e.g., Gillen-O'Neel and Fuligni 2013; Jose et al. 2012) could be combined with qualitative elements (e.g., interviews or focus groups with students; Zumbrunn et al. 2014) to get a more complete picture of students' perceived social experiences at school. In addition, the complex associations between the introduced variables definitely need further investigation apart from testing for group differences, similarity of relations between groups and mediation effects. Future studies might employ multi-level modelling by bringing in level 2 predictors in order to test for the explanative power of school-level predictors. In addition, moderation analyses may help to detect interaction effects. Finally, latent profile analysis would allow for a person-centred perspective by exploring whether different profiles of students with regard to the quality of supportive relationships could be identified. These profiles may differ pertaining to their association with SOBS and various students' outcomes.

\section{Conclusion and implications}

The results of the present study provide additional evidence of the important interrelations between supportive relationships with teacher, parents and peers, students' SOBS and their academic (achievement, school absenteeism) and non-academic (life satisfaction) outcomes, confirming the function of SOBS as a mediator. Although one must keep in mind that the effects were not very large, the results still reveal 
the need to foster supportive relationships with teachers, classmates, and parents, as they go hand-in-hand with higher SOBS, life satisfaction, and achievement, whereas school absenteeism is lower the greater the quality of supportive relationships is. Thus, supportive relationships are not only important for students' optimal functioning in school, but they are also important correlates of students' well-being as indicated by their general life satisfaction (see also Suldo et al. 2008). In order to establish a supportive relational environment, all actors need to possess adequate socio-emotional skills, as relationships are reciprocal and dynamic (Jennings and Greenberg 2009; St-Amand et al. 2017). Explicit interventions that foster those skills should be more widely implemented in schools worldwide and in Austria specifically (see, for example, the program 'Lions Quest', which trains teachers' social and emotional learning that gains in popularity in Austria; Talvio et al. 2019).

Finally, the results mainly revealed small differences between groups of students. However, regarding the scale mean values, overall, male students and students from migration backgrounds tended to report lower values in the assessed factors, particularly concerning perceived teacher fairness. Thus, teachers should make an effort to ensure fair and respectful teacher-student interactions, in particular when interacting with male students and students with migration backgrounds.

Funding Open access funding provided by Paris Lodron University of Salzburg.

Open Access This article is licensed under a Creative Commons Attribution 4.0 International License, which permits use, sharing, adaptation, distribution and reproduction in any medium or format, as long as you give appropriate credit to the original author(s) and the source, provide a link to the Creative Commons licence, and indicate if changes were made. The images or other third party material in this article are included in the article's Creative Commons licence, unless indicated otherwise in a credit line to the material. If material is not included in the article's Creative Commons licence and your intended use is not permitted by statutory regulation or exceeds the permitted use, you will need to obtain permission directly from the copyright holder. To view a copy of this licence, visit http://creativecommons.org/licenses/by/4. $0 \%$.

\section{References}

Ahmadi, F., \& Ahmadi, S. (2020). School-related predictors of students' life-satisfaction: the mediating role of school belongingness. Contemporary School Psychology, 24, 196-205.

Aldridge, J. M., McChesney, K., \& Afari, E. (2020). Associations between school climate and student life satisfaction: resilience and bullying as mediating factors. Learning Environments Research, 23, $129-150$.

Allen, K. A., \& Bowles, T. (2012). Belonging as a guiding principle in the education of adolescents. Australian Journal of Educational \& Developmental Psychology, 12, 108-119.

Allen, K., Kern, M.L., Vella-Brodrick, D., Hattie, J., \& Waters, L. (2018). What schools need to know about fostering school belonging: a meta-analysis. Educational Psychology Review, 30(1), 1-34.

Allen, K.-A. A., Vella-Brodrick, D., \& Waters, L. (2016). Fostering school belonging in secondary schools using a socio-ecological framework. The Educational and Developmental Psychologist, 33(1), 97-121.

Arends, F., \& Visser, M. (2019). The contribution of South African teachers to students' sense of belonging and mathematics achievement. South African Journal of Childhood Education, 9(1), a697. https://doi. org/10.4102/sajce.v9i1.697.

Arslan, G. (2018). Exploring the association between school belonging and emotional health among adolescents. International Journal of Educational Psychology, 7(1), 21-41.

Baumeister, R.F., \& Leary, M.R. (1995). The need to belong: desire for interpersonal attachments as a fundamental human motivation. Psychological Bulletin, 117(3), 497-529. 
Bergin, C., \& Bergin, D. (2009). Attachment in the classroom. Educational Psychological Review, 21, 141-170.

Bond, L., Butler, H., Thomas, L., Carlin, J., Glover, S., Bowes, G., \& Patton, G. (2007). Social and school connectedness in early secondary school as predictors of late teenage substance use, mental health, and academic outcomes. Journal of Adolescent Health, 40, 357.e9-357.e18.

Bronfenbrenner, U. (1977). Toward an experimental ecology of human development. American Psychologist, 32(7), 513-530.

Chen, F.F. (2007). Sensitivity of goodness of fit indexes to lack of measurement invariance. Structural Equation Modeling, 14, 464-504.

Cheung, G.W., \& Rensvold, R.B. (2002). Evaluating goodness-of-fit indexes for testing measurement invariance. Structural Equation Modelling, 9(2), 233-255.

Chiu, M. M., Pong, S.-L., Mori, I., \& Chow, B. W.-Y. (2012). Immigrant students' emotional and cognitive engagement at school: a multilevel analysis of students in 41 countries. Journal of Youth and Adolescence, 41, 1409-1425.

Cohen, J. (1988). Statistical power analysis for the behavioral sciences (2nd edn.). Hillsdale: Erlbaum.

Datu, J. A. D., \& Valdez, J.P. M. (2019). Psychological capital is associated with higher levels of life satisfaction and school belongingness. School Psychology International, 40(4), 331-346.

Demanet, J., \& van Houtte, M. (2012). School belonging and school misconduct: the differing role of teacher and peer attachment. Journal of Youth and Adolescence, 41, 499-514.

Diener, E. (2000). Subjective well-being: The science of happiness and a proposal for a national index. American Psychologist, 55, 34-43.

Eder, F. (1995). Das Befinden von Kindern und Jugendlichen in der Schule. Wien, Innsbruck: Studienverlag.

Eder, F. (2007). Das Befinden von Kindern und Jugendlichen in der österreichischen Schule. Befragung 2005. Wien, Innsbruck: Studienverlag.

Gillen-O’Neel, C., \& Fuligni, A. (2013). A longitudinal study of school belonging and academic motivation across high school. Child Development, 84(2), 678-692.

Goodenow, C., \& Grady, K.E. (1993). The relationship of school belonging and friends' values to academic motivation among urban adolescent students. Journal of Experimental Education, 62(1), 60-71.

Hagenauer, G., \& Oberwimmer, K. (2019). Zum Zusammenhang zwischen Hausaufgabenpraxis und Leseleistung: Ergebnisse aus PIRLS 2006, 2011 und 2016. In C. Wallner-Paschon \& U. ItzlingerBruneforth (Eds.), Lesekompetenz der 10-Jährigen im Trend - Vertiefende Analysen zu PIRLS (pp. 221-237). Graz: Leykam.

Hagenauer, G., \& Volet, S.E. (2014). Student-teacher relationship at university: an important yet underresearched field. Oxford Review of Education, 40(3), 370-388.

Hagenauer, G., Gläser-Zikuda, M., \& Moschner, B. (2018). University students' emotions, life-satisfaction and study commitment: a self-determination theoretical approach. Journal of Further and Higher Education, 42(6), 808-826.

Ham, S.-H., Yang, K.E., \& Cha, Y.-K. (2017). Immigrant integration policy for future generations? A cross-national multilevel analysis of immigrant-background adolescents' sense of belonging at school. International Journal of Intercultural Relations, 60, 40-50.

Hu, L., \& Bentler, P. M. (1999). Cut-off criteria for fit indexes in covariance structure analysis: Conventional criteria versus new alternatives. Structural Equation Modeling, 6, 1-55.

Huyge, E., Van Maele, D., \& Van Houtte, M. (2015). Does students' machismo fit in school? Clarifying the implications of traditional gender role ideology for school belonging. Gender and Education, 27(1), 1-18.

Jennings, P. A., \& Greenberg, M. T. (2009). The prosocial classroom: teacher social and emotional competence in relation to student and classroom outcomes. Review of Educational Research, 79, 491-525.

Jose, P.E., Ryan, N., \& Pryor, J. (2012). Does social connectedness promote a greater sense of well-being in adolescence over time? Journal of Research on Adolescence, 22(2), 235-251.

Kelloway, E. K. (2017). Using Mplus for structural equation modelling: a researchers' guide. Thousand Oaks: SAGE.

Klaeijsen, A., Vermeulen, M., \& Martens, R. (2018). Teachers' innovative behaviour: the importance of basic psychological need satisfaction, intrinsic motivation, and occupational self-efficacy. Scandinavian Journal of Educational Research, 62(5), 769-782.

Kleinke, K., Schlüter, E., \& Christ, O. (2017). Strukturgleichungsmodelle in Mplus. Oldenburg: de Gruyter.

Korpershoek, H., Canrinus, E. T., Fokkens-Bruinsma, M., \& de Boer, H. (2020). The relationships between school belonging, and students' motivational, socio-emotional, behavioural, and academic outcomes in secondary education: a meta-analytic review. Research Papers in Education, 35(6), 641-680. 
Longaretti, L. (2020). Perceptions and experiences of belonging during the transition from primary to secondary education. Australian Journal of Teacher Education, 45(1), 30-46.

Martin, A.J., \& Dowson, M. (2009). Interpersonal relationships, motivation, engagement, and achievement: Yields for theory, current issues, and educational practice. Review of Educational Research, 79(1), 327-365.

McNeely, C., \& Falci, C. (2004). School connectedness and the transition into and out of health-risk behaviour among adolescents: a comparison of social belonging and teacher support. Journal of School Health, 74(7), 284-292.

Millsap, R.E. (2012). Statistical approaches to measurement invariance. New York: Routledge.

Muthén, L.K., \& Muthén, B.O. (1998-2017). Mplus user's guide (8th edn.). Los Angeles: Muthén \& Muthén.

Newman, B. M., Lohman, B. J., \& Newman, P. R. (2007). Peer group membership and a sense of belonging: their relationship to adolescent behaviour problems. Adolescence, 42, 241-263.

OECD (2016). PISA 2015 results (volume I). Excellence and equity in education. Paris: OECD Publishing. https://doi.org/10.1787/9789264266490-en.

OECD (2017a). PISA 2015. Technical report. Paris: OECD Publishing. http://www.oecd.org/pisa/ sitedocument/PISA-2015-technical-report-final.pdf

OECD (2017b). PISA 2015 results (volume III): students' well-being. Paris: OECD Publishing. https://doi. org/10.1787/9789264273856-en.

OECD (2019a). PISA 2018: assessment and analytical framework. Paris: OECD Publishing. https://doi. org/10.1787/38a34352-en.

OECD (2019b). PISA 2018 results (volume III): what school life means for students' lives. Paris: OECD Publishing. https://doi.org/10.1787/acd78851-en.

Osterman, K.F. (2000). Students' need for belonging in the school community. Review of Educational Research, 70(3), 333-367.

Pomerantz, E. M., \& Eaton, M. M. (2001). Maternal intrusive support in the academic context: transactional socialization processes. Developmental Psychology, 37(2), 174-186.

Ryan, R. M., \& Deci, E.L. (2000). Self-determination theory and the facilitation of intrinsic motivation, social development, and well-being. Am Psychol, 55(1), 68-78.

Ryan, R. M., \& Deci, E. L. (2017). Self-determination theory. New York, London: Guilford.

Sakiz, G. (2012). Perceived instructor affective support in relation to academic emotions and motivation in college. Educational Psychology, 32(1), 63-79.

Sakiz, G., Pape, S. J., \& Woolfolk-Hoy, A. (2012). Does perceived teacher affective support matter for middle school students in mathematics classroom? Journal of School Psychology, 50(2), 235-255.

Sälzer, C. (2010). Schule und Absentismus. Wiesbaden: VS.

Schachner, M.K., Schwarzenthal, M., van de Vijver, F. J.R., \& Noack, P. (2018). How all students can belong and achieve: effects of the cultural diversity climate amongst students of immigrant and nonimmigrant background in Germany. Journal of Educational Psychology, 11(4), 703-716.

Schermelleh-Engel, K., Moosbrugger, H., \& Müller, H. (2003). Evaluating the fit of structural equation models: tests of significance and descriptive goodness-of-fit-measures. Methods of Psychological Research Online, 8(2), 23-74.

Slaten, C. D., Ferguson, J. K., Allen, K.-A., Brodrick, D.-V., \& Waters, L. (2016). School belonging: a review of the history, current trends, and future directions. The Educational and Developmental Psychologist, 33(1), 1-15.

St-Amand, J., Girard, S., \& Smith, J. (2017). Sense of belonging at school: Defining attributes, determinants, and sustaining strategies. IAFOR Journal of Education, 5(2), 105-119.

Stamm, M. (2006). Schulabsentismus. Anmerkungen zu Theorie und Empirie einer vermeintlichen Randerscheinung schulischer Bildung. Zeitschrift für Pädagogik, 2, 285-303.

Suchań, B., \& Breit, S. (Eds.). (2016). PISA 2015. Grundkompetenzen am Ende der Pflichtschulzeit im internationalen Vergleich. Graz: Leykam.

Suldo, S. M., Shaffer, E. J., \& Riley, K. N. (2008). A social-cognitive-behavioral model of academic predictors of adolescents' life satisfaction. School Psychology Quarterly, 23(1), 56-69.

Talvio, M., Hietajärvi, L., Matischek-Jauk, M., \& Lonka, K. (2019). Do Lions Quest (LQ) workshops have a systematic impact on teachers' social and emotional learning (SEL)? Samples from nine different countries. Electronic Journal of Research in Educational Psychology, 17(2), 465-494. https://doi.org/ 10.25115/ejrep.v17i48.216.

Tian, L., Tian, Q., \& Huebner, E.S. (2016). School-related social support and adolescents' school-related subjective well-being: the mediating role of basic psychological needs satisfaction at school. Social Indicators Research, 128(1), 105-129. 
Wormington, S. V., Anderson, K. G., Schneider, A., Tomlinson, K. L., \& Brown, S. A. (2016). Peer victimization and adolescent adjustment: does school belonging matter? Journal of School Violence, 15, $1-21$.

Xiang, P., Ağbuğa, B., Liu, J., \& McBride, R.E. (2017). Relatedness need satisfaction, intrinsic motivation, and engagement in secondary school physical education. Journal of Teaching in Physical Education, 36(3), 340-352.

Zumbrunn, S., McKim, C., Buhs, E., \& Hawley, L. R. (2014). Support, belonging, motivation, and engagement in the college classroom: a mixed method study. Instructional Science, 42, 661-684. 